\title{
Hyperglycemia and Hyperlipidemia Act Synergistically to Induce Renal Disease in LDL Receptor-Deficient BALB Mice
}

\author{
Min W. Spencer ${ }^{a}$ Anja S. Mühlfeld ${ }^{a, c}$ Stephan Segerer ${ }^{d}$ Kelly L. Hudkins ${ }^{a}$ \\ Elizabeth Kirk ${ }^{b}$ Renée C. LeBoeuf ${ }^{b}$ Charles E. Alpers ${ }^{a}$ \\ Departments of a Pathology, and ${ }^{\mathrm{b} P a t h o b i o l o g y, ~ a n d ~ N u t r i t i o n a l ~ S c i e n c e s ~ I n t e r d i s c i p l i n a r y ~ P r o g r a m, ~}$ \\ University of Washington, Seattle, Wash., USA; 'Division of Nephrology and Immunology, University of Aachen, \\ Aachen, and, dMedizinische Poliklinik, Klinikum der Innenstadt, University of Munich, Munich, Germany
}

\section{Key Words}

BALB.LDLR-/- • Hyperlipidemia • Hyperglycemia • Diabetic nephropathy · Tubular degeneration • Apoptosis - Extracellular matrix

\begin{abstract}
Diabetic nephropathy is the leading cause of end-stage renal disease in Western countries, but only a portion of diabetic patients develop diabetic nephropathy. Dyslipidemia represents an important aspect of the metabolic imbalance in diabetic patients. In this study, we addressed the impact of combined hyperlipidemia and hyperglycemia on renal pathology. Kidneys from wildtype (WT) or LDL receptor-deficient BALB/cBy mice (BALB.LDLR-/-) were examined at 22 weeks of age. Diabetes was induced by administration of streptozotocin and mice were randomly assigned to either standard chow or Western diet. Chow fed BALB.LDLR-/- mice did not demonstrate renal abnormalities, whereas BALB. LDLR-/- mice fed a Western diet showed occasional glomerular and tubulointerstitial foam cells. Diabetic WT mice had modestly increased glomerular cellularity and extracellular matrix. Hyperlipidemic and diabetic BALB.LDLR-/mice exhibited an increase in glomerular cellularity and
\end{abstract}

\section{KARGER}

Fax +41613061234

E-Mail karger@karger.ch

www.karger.com
(C) 2004 S. Karger AG, Basel

0250-8095/04/0241-0020\$21.00/0

Accessible online at:

www. karger.com/ajn extracellular matrix, accumulation of glomerular and tubulointerstitial foam cells and mesangial lipid deposits. The tubular epithelium demonstrated pronounced lipid induced tubular degeneration with increased tubular epithelial cell turnover. Hyperlipidemia and hyperglycemia seem to act synergistically in inducing renal injury in the BALB.LDLR-/- mouse. This model of diabetic nephropathy is unique in its development of tubular lesions and may represent a good model for hyperlipidemia-exacerbated diabetic nephropathy.

Copyright $@ 2004$ S. Karger AG, Basel

\section{Introduction}

The prevalence of type II diabetes mellitus is rising in all Western countries and diabetic nephropathy has become the leading cause for end-stage renal disease (ESRD) in the US, accounting for 33\% of patients on kidney replacement therapy in 1999 [1]. In diabetic patients, hyperglycemia has been established as a major risk factor for renal failure $[2,3]$ leading to thickening of the glomerular and tubular basement membranes and expansion of extracellular matrix, and eventually to the development of glomerulosclerosis and renal failure. However, since 
only a portion of diabetic patients develop clinically apparent nephropathy [4-7], it is likely that factors other than hyperglycemia influence the incidence and progression of diabetic nephropathy.

Hyperlipidemia represents an established risk factor for the development of atherosclerosis and vascular disease in diabetes mellitus [8]. With regard to renal disease, animal studies indicate that hyperlipidemia alone can induce renal injury characterized by increased glomerular cellularity, accumulation of mesangial matrix and lipid deposition in the mesangium [9-14]. Nevertheless, the influence of hyperlipidemia on the initiation and progression of diabetic nephropathy remains incompletely understood. In humans, studies of patients with early onset insulin-dependent diabetes mellitus and nephropathy have established a relationship between hyperlipidemia and diabetic nephropathy and have provided some evidence that hyperlipidemia may accelerate the progression of diabetic nephropathy $[15,16]$. In patients with type II diabetes the current data are less clear, with some studies showing a correlation between plasma lipids and progression of diabetic nephropathy $[17,18]$ while others could not find an association between hyperlipidemia and diabetic nephropathy $[19,20]$. A few studies with lipid-lowering agents report beneficial effects of these drugs on diabetic nephropathy with decrease in proteinuria and slowing of the decline in glomerular filtration rate (GFR) [2123]. However, the mechanism by which hyperglycemia and hyperlipidemia exert their harmful effect on the kidney remains largely unknown, and animal models suitable for the investigation of diabetic nephropathy have major limitations. Currently, the most common animal model for diabetic nephropathy of type I diabetes mellitus involves the use of the islet toxin streptozotocin (STZ). Animals with STZ-induced hyperglycemia display renal pathology mostly in the glomeruli, while the tubulointerstitium and vasculature are generally spared and animals do not progress to renal failure. Animal models that more closely reproduce clinical and pathological features of human disease are needed in order to investigate the different sequelae of the metabolic disturbances in diabetes mellitus, especially the influence of hyperlipidemia. Here we describe early renal pathology in a new rodent model of genetic and alimentary hyperlipidemia, the BALB. LDLR-/- mouse. We report that these hyperlipidemic mice, made diabetic by STZ treatment, display both glomerular and tubular pathology, and that hyperglycemia and hyperlipidemia seem to act synergistically in the progression of renal disease.

\section{Methods and Materials}

\section{Animal Study}

Female BALB/cByJ (BALB) wild type and male C57BL/6JLDLr $^{\text {tmlHer }}$ (LDLR-/-) mice were obtained from Jackson Laboratory (Bar Harbor, Me., USA). Mice deficient in the LDL receptor were backcrossed for 8 generations onto the BALB/cByJ genetic background. After 8 generations of backcrossing less than $0.4 \%$ of unlinked C57BL/6 genes are retained in the new CBy.129S7(B6)Ldlr ${ }^{\text {tm1Her }}$ BALB.LDLR-deficient mice. After that, mice heterozygous for the LDL receptor mutation were then intercrossed to produce mice homozygous for the disrupted LDL receptor (BALB. LDLR-/-). Littermate controls with and without the LDL receptor mutation were used in the study. All animals were maintained in the animal care facility of the University of Washington in a temperature-controlled room $\left(25^{\circ} \mathrm{C}\right)$ with fixed 12-hour light/dark cycle. They had free access to food and water but food was removed $4 \mathrm{~h}$ before collection of blood samples from the retro-orbital plexus or at necropsy. Blood was collected in tubes containing $1 \mathrm{~m} M$ EDTA and plasma was stored at $-70^{\circ} \mathrm{C}$ until analysis.

\section{Experimental Design}

Female mice of BALB and BALB.LDLR-/- strains were used in this study. Mice were initially maintained on pelleted rodent chow (Wayne Rodent BLOX 8604, Teklad, Madison, Wisc., USA) and randomly assigned to one of 4 treatment groups: rodent chow $(\mathrm{n}=6$ for BALB and $\mathrm{n}=6$ for BALB.LDLR-/-), rodent chow and STZ ( $\mathrm{n}=$ 6 for BALB and $n=7$ for BALB.LDLR-/-), Western diet ( $\mathrm{n}=7$ for BALB and $\mathrm{n}=10$ for BALB.LDLR-/-) and Western diet and STZ ( $\mathrm{n}=6$ for BALB and $\mathrm{n}=13$ for BALB.LDLR-/-). Rodent chow contained $4 \%$ fat, $24 \%$ protein and $4.5 \%$ crude fiber. The Western diet contained $21 \%$ fat and $0.15 \%$ cholesterol (TD 88137, Harlan Teklad BLOX, Madison, Wisc., USA). Hyperglycemia was induced by intraperitoneal injection of the islet toxin STZ (STZ; $40 \mathrm{mg} / \mathrm{kg}$ body weight) for 5 consecutive days at 7 and 9 weeks of age. Non-STZ groups were injected with citrate buffer. At 12 weeks of age, diet groups within STZ and citrate-treated mice were assigned to rodent chow or Western diet. Diets were fed for 10 weeks. The study was originally designed to evaluate disease in large extrarenal arterial vessels; the opportunity to study morphologic changes in the kidney developed after all the animals had been sacrificed.

The animal study was reviewed and approved by the Animal Care and Use Committee of the University of Washington according to the principles of laboratory animal care.

\section{Analytical Procedures}

Animals in this study were examined retrospectively so that availability of serum samples for evaluation of laboratory data was limited to the assays reported below.

Plasma glucose levels were measured colorimetrically (Trinder Glucose 500 Diagnostic kit, Sigma, St. Louis, Mo., USA). Plasma total cholesterol levels were determined using a colorimetric kit (Diagnostic Chemicals Limited, Oxford, Conn., USA) with cholesterol standards (Boehringer Mannheim, Indianapolis, Ind., USA). Plasma triglyceride levels were determined colorimetrically following the removal of free glycerol (Diagnostic kit \#450032, Boehringer Mannheim). Plasma BUN levels were assessed with a colorimetric assay (Diagnostic kit \#535-A, Sigma). 
Tissue Preparation and Histological Staining

Mice were sacrificed at 22 weeks of age by cervical dislocation and whole animals were perfused with $10 \mathrm{ml}$ of antioxidant buffer (100 $\mu M$ DTPA, $100 \mu M$ BHT, $0.1 \%$ ethanol in PBS, pH 7.4) via the left ventricle. Kidneys were removed and fixed in $10 \%$ neutral buffered formalin or in methyl Carnoy's solution for histological examination and in half-strength Karnovsky's solution (1\% paraformaldehyde and $1.25 \%$ glutaraldehyde in $0.1 \mathrm{M}$ sodium cacodylate buffer, pH 7.0) for electron microscopy. Tissues for histology were processed following standard protocols and cut into $2-\mu \mathrm{m}$ sections for periodic acid-methenamine silver (PAM) staining and into $4-\mu \mathrm{m}$ sections for hematoxylin-eosin (HE) staining, immunohistochemistry and TUNEL staining.

\section{Immunohistochemistry and TUNEL Staining}

For immunohistochemistry $4-\mu \mathrm{m}$-thick tissue sections were deparaffinized in xylene and rehydrated through graded ethanol. Antigen retrieval was performed by steam heating in Antigen Unmasking Solution when necessary (Vector Laboratories, Burlingame, Calif., USA). Endogenous peroxidases were blocked by incubation with 3\% hydroxygen peroxide for $5 \mathrm{~min}$ and endogenous biotin was blocked using the Avidin/Biotin blocking kit (Vector). Primary antibodies were diluted in PBS containing 1\% BSA (Sigma, St. Louis, Mo., USA) and slides were incubated for $1 \mathrm{~h}$ at room temperature. Sections were washed in PBS and then incubated with appropriate biotinylated secondary antibodies. The ABC-Elite Reagent (Vector) was utilized for signal amplification, and 3,3'-diaminobenzidine (DAB; Sigma) with nickel enhancement was used as chromogen, resulting in a black color product. Sections were counterstained with periodic acid Schiff/methyl-green, dehydrated and coverslipped. Macrophages were detected using a rat anti-mouse MAC-2 antibody as previously described [24] (Cederlane, Ontario, Canada) and a mouseadsorbed anti-rat antibody was utilized as secondary anti-body (Vector Laboratories). A monoclonal mouse IgG2a antibody was used for detection of mesangial $\alpha$-smooth muscle actin expression (as previously described [25]) (clone 1A4, DAKO, Carpinteria, Calif., USA). Here the secondary antibody was a monoclonal rat anti-mouse IgG2a anti-body (Pharmingen, San Diego, Calif., USA). Cellular proliferation was assessed using a mouse monoclonal anti-human PCNA antibody [as previously described, 26] (Oncogene Research Products, Cambridge, Mass., USA) with a monoclonal rat anti-mouse secondary antibody (Vector Laboratories).

TUNEL staining was performed using a TdT-FragEL DNA fragmentation detection kit (Oncogene Research Products) according to the manufacturer's instructions and as previously described in detail [27]. In brief, tissue sections were deparaffinized, rehydrated, permeabilized in $20 \mu \mathrm{g} / \mathrm{ml}$ proteinase $\mathrm{K}$ in $10 \mathrm{mM}$ tris, $\mathrm{pH} 8.0$ and blocked for endogenous peroxidases in $3 \%$ hydroxygen peroxide in methanol. Slides were then labeled with TdT labeling reaction mix and incubated for $1.5 \mathrm{~h}$ at $37^{\circ} \mathrm{C}$. Signal was amplified using the $\mathrm{ABC}$-Elite reagent (Vector) and visualized with 3,3'-diaminobenzidine and nickel enhancement. Counterstaining was performed with periodic acid-Schiff/methyl green dyes.

\section{Electron Microscopy}

Randomly selected cases of hyperlipidemic and hyperglycemic mice were utilized for transmission electron microscopy. The protocol for tissue preparation and staining has been described previously [28]. Grids were scanned using a Philips 410 electron microscope (Philips, Eindhoven, The Netherlands).
Quantitative Analysis and Statistics

Morphometric analysis was performed on HE and PAM stained kidney sections. Fifteen random glomerular cross-sections were photographed by an examiner blinded for the origin of the sample using a digital camera (Olympus DP11, Olympus America, Melville, N.Y., USA). The images were imported into the Image Pro Plus software (Media Cybernetics, Silver Spring, Md., USA) and the number of nuclei, the amount of mesangial matrix and the glomerular tuft area were quantified. The number of macrophages and PCNA-positive cells was counted in at least 40 glomerular cross section or high power fields per slide. Glomerular $\alpha$-smooth muscle actin expression in mesangial areas was assessed semi-quantitatively on a scale from 0 (negative) to 4 (strong expression in the whole mesangium) as previously described [29].

Statistical differences were assessed using the SPSS program (SPSS Inc., Chicago, Ill., USA). Values are expressed as mean \pm SEM. Groups were compared using ANOVA with Tukey's posthoc test. $\mathrm{p}<0.05$ was considered statistically significant.

\section{Results}

\section{Plasma Cholesterol, Triglycerides and Blood Glucose \\ Levels}

Total cholesterol levels were measured in mice of the different experimental groups. LDL receptor deficiency in BALB mice alone led to a modest increase in plasma cholesterol content, but values did not reach levels of statistical significance. In contrast, total cholesterol levels increased threefold in BALB.LDLR-/- animals fed the Western diet as compared to chow fed BALB.LDLR-/mice, and increased further when mice were made diabetic with STZ treatment (table 1). Serum triglyceride levels were not significantly different in the different experimental groups.

STZ treatment of wild-type and BALB.LDLR-/- mice led to a strong increase in blood glucose from $78 \mathrm{mg} / \mathrm{dl}$ (control mice) to over $300 \mathrm{mg} / \mathrm{dl}$ in treatment groups (BALB, STZ $396 \pm 76 \mathrm{mg} / \mathrm{dl}$; BALB, STZ, Western diet $343 \pm 83 \mathrm{mg} / \mathrm{dl}$; BALB.LDLR-/-, STZ, Western diet $471 \pm 79 \mathrm{mg} / \mathrm{dl}$ ). However, STZ treated, chow fed BALB.LDLR-/- mice had only slightly elevated glucose levels of $180 \pm 21 \mathrm{mg} / \mathrm{dl}$. This was most likely due to a commercial lot of STZ with lower potency or variability in individual responsiveness to STZ.

\section{Hyperlipidemia and Hyperglycemia Act Synergistically to Induce Glomerular Pathology in BALB Mice}

During the time course of this study ( 10 weeks of Western diet and 12 weeks of hyperglycemia) glomerular morphology was only modestly altered by either hyperglycemia or hyperlipidemia alone. BALB.LDLR-/- mice did 
Table 1. Plasma levels for cholesterol, triglycerides, blood glucose and blood urea nitrogen

\begin{tabular}{|c|c|c|c|c|}
\hline & $\begin{array}{l}\text { Cholesterol } \\
\mathrm{mg} / \mathrm{dl}\end{array}$ & $\begin{array}{l}\text { Triglycerides } \\
\mathrm{mg} / \mathrm{dl}\end{array}$ & $\begin{array}{l}\text { Blood glucose } \\
\mathrm{mg} / \mathrm{dl}\end{array}$ & $\begin{array}{l}\text { BUN } \\
\mathrm{mg} / \mathrm{dl}\end{array}$ \\
\hline $\begin{array}{l}1 \\
\text { BALB } \\
\text { Chow }\end{array}$ & $\begin{array}{l}81 \pm 9 \\
* \text { vs. } 6 \\
* * \text { vs. } 8\end{array}$ & $104 \pm 18$ & $\begin{array}{r}78 \pm 7 \\
* * \text { vs. } 8\end{array}$ & $\begin{array}{l}22 \pm 2 \\
* * \text { vs. } 7 \\
* * * \text { vs. } 8\end{array}$ \\
\hline $\begin{array}{l}2 \\
\text { BALB } \\
\text { Western diet }\end{array}$ & $\begin{array}{l}174 \pm 10 \\
* * \text { vs. } 8\end{array}$ & $104 \pm 22$ & $\begin{array}{l}141 \pm 11 \\
* * \text { vs. } 8\end{array}$ & $\begin{array}{l}22 \pm 3 \\
* * \text { vs. } 7 \\
* * * \text { vs. } 8\end{array}$ \\
\hline $\begin{array}{l}3 \\
\text { BALB } \\
\text { Chow } \\
\text { STZ }\end{array}$ & $\begin{array}{l}148 \pm 30 \\
* * \text { vs. } 8\end{array}$ & $163 \pm 16$ & $396 \pm 76$ & $\begin{array}{l}36 \pm 4 \\
* * \text { vs. } 8\end{array}$ \\
\hline $\begin{array}{l}4 \\
\text { BALB } \\
\text { Western diet } \\
\text { STZ }\end{array}$ & $\begin{array}{l}139 \pm 23 \\
* \text { vs. } 6 \\
* * * \text { vs. } 8\end{array}$ & $109 \pm 22$ & $344 \pm 83$ & $\begin{array}{l}32 \pm 4 \\
* * * \text { vs. } 8\end{array}$ \\
\hline $\begin{array}{l}5 \\
\text { BALB.LDLR-/- } \\
\text { Chow }\end{array}$ & $\begin{array}{l}193 \pm 25 \\
* * \text { vs. } 8\end{array}$ & $170 \pm 19$ & $\begin{array}{l}122 \pm 11 \\
* * \text { vs. } 8\end{array}$ & $\begin{array}{l}36 \pm 3 \\
* * \text { vs. } 8\end{array}$ \\
\hline $\begin{array}{l}6 \\
\text { BALB.LDLR-/- } \\
\text { Western diet }\end{array}$ & $\begin{array}{l}572 \pm 29 \\
* \text { vs. } 1,4\end{array}$ & $180 \pm 22$ & $\begin{array}{l}141 \pm 4 \\
* * * \text { vs. } 8\end{array}$ & $\begin{array}{l}30 \pm 4 \\
* \text { vs. } 7 \\
* * * \text { vs. } 8\end{array}$ \\
\hline $\begin{array}{l}7 \\
\text { BALB.LDLR-/- } \\
\text { Chow } \\
\text { STZ }\end{array}$ & $\begin{array}{l}227 \pm 14 \\
* * \text { vs. } 8\end{array}$ & $238 \pm 32$ & $\begin{array}{l}180 \pm 21 \\
* \text { vs. } 8\end{array}$ & $\begin{array}{l}51 \pm 8 \\
* \text { vs. } 6 \\
* * \text { vs. } 1,2\end{array}$ \\
\hline $\begin{array}{l}8 \\
\text { BALB.LDLR-/- } \\
\text { Western diet } \\
\text { STZ }\end{array}$ & $\begin{array}{l}724 \pm 132 \\
* * \text { vs. } 1,2,3,5,7 \\
* * * \text { vs. } 4\end{array}$ & $558 \pm 190$ & $\begin{array}{l}471 \pm 79 \\
* * \text { vs. } 1,2,5,7 \\
* * * \text { vs. } 6\end{array}$ & $\begin{array}{l}69 \pm 4 \\
* * \text { vs. } 3,5 \\
* * * \text { vs. } 1,2,4,6\end{array}$ \\
\hline
\end{tabular}

Values are expressed as mean \pm standard error of the mean. Significant differences expressed as $* \mathrm{p}<0.05,{ }^{* *} \mathrm{p}<0.01, * * * \mathrm{p}<0.001$. not display remarkable changes in glomerular architecture. Glomeruli from BALB.LDLR-/- animals fed a Western diet (hyperlipidemic mice) showed occasional foam cells and fat droplets in the mesangium. Overall glomerular cellularity was not altered and matrix was only slightly, but not significantly, increased. Wild-type mice treated with STZ to induce hyperglycemia showed a small increase in glomerular cellularity $(45.7 \pm 3.4$ cells/glomerular cross-section (gcs) for diabetic mice vs. $39.7 \pm$ 2.0 cells/gcs in wild type controls) and matrix (241.8 \pm $30.1 \mu \mathrm{m}^{2}$ in mice made diabetic vs. $139.3 \pm 26.1 \mu \mathrm{m}^{2}$ in BALB control animals), both not significantly different from wild type controls (fig. 1, 2). In contrast, animals whose kidneys were exposed to both hyperlipidemia and hyperglycemia together showed an increase in glomerular cell number $(59.8 \pm 2.5$ cells/gcs vs. $39.7 \pm 2.4$ in chowfed BALB mice, $\mathrm{p}<0.001$; fig. 1). In addition, hyperlipidemic BALB.LDLR-/- mice with STZ-induced hyperglycemia also demonstrated a significant increase in glomerular matrix compared to diabetic control animals (423 \pm 24 vs. $242 \pm 30 \mu \mathrm{m}^{2}, \mathrm{p}<0.001$; fig. 2). Both increased glomerular cellularity and matrix led to the expansion of the glomerular tuft area from 2,546 $\pm 208 \mu \mathrm{m}^{2}$ in control animals to $4,440 \pm 145 \mu \mathrm{m}^{2}$ in hyperglycemic BALB. LDLR-/- mice fed the Western diet $(\mathrm{p}<0.001)$. The glomeruli of these mice were frequently infiltrated with foam cells and the mesangium commonly showed fat deposits (fig. 3). However, neither mesangiolysis nor extensive fo- 


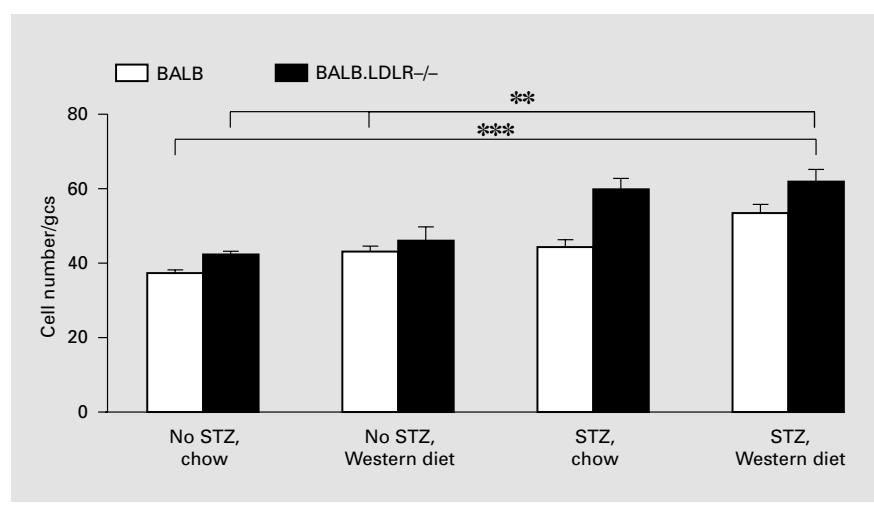

Fig. 1. Cell number per glomerular cross-section in experimental groups expressed as mean \pm SEM. BALB.LDLR-/- mice on a Western diet with STZ-induced diabetes are significantly different from BALB controls on chow at a level of $* * * p<0.001$ and significantly different from BALB.LDLR-/- controls on chow and BALB control mice on a Western diet at a level of ** $\mathrm{p}<0.01$.

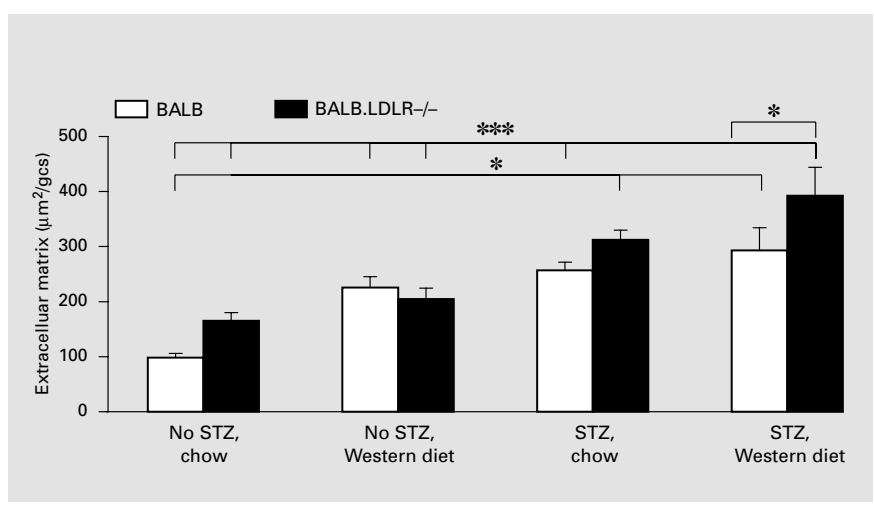

Fig. 2. Extracellular matrix per glomerular cross section in experimental groups, expressed as mean \pm SEM. Significant differences between diabetic BALB.LDLR-/- mice on Western diet and diabetic BALB mice on a Western diet at a level of $* p<0.05$ and between diabetic BALB.LDLR-/- mice on Western diet and chow fed BALB controls, chow fed BALB.LDLR-/- mice, BALB and BALB. LDLR-/- on a Western diet as well as chow-fed diabetic BALB mice at a level of ${ }^{* * *} \mathrm{p}<0.001$. Chow-fed BALB control mice show significantly less glomerular matrix than their diabetic and hyperlipidemic counterparts.
Fig. 3. Glomerular architecture, periodic acid methenamine silver stain. A Normal glomerular structures in BALB control mice. B BALB mouse, STZ treatment leads to slight increase in extracellular matrix and mild hypercellularity. C Normal glomerular architecture of a BALB.LDLR-/- mouse, fed a Western diet. D BALB.LDL receptor knockout mouse, Western diet, STZ treatment. The arrows point to foam cells, arrowheads indicate mesangial lipid deposits. The glomerulus shows an increase in glomerular matrix and hypercellularity.
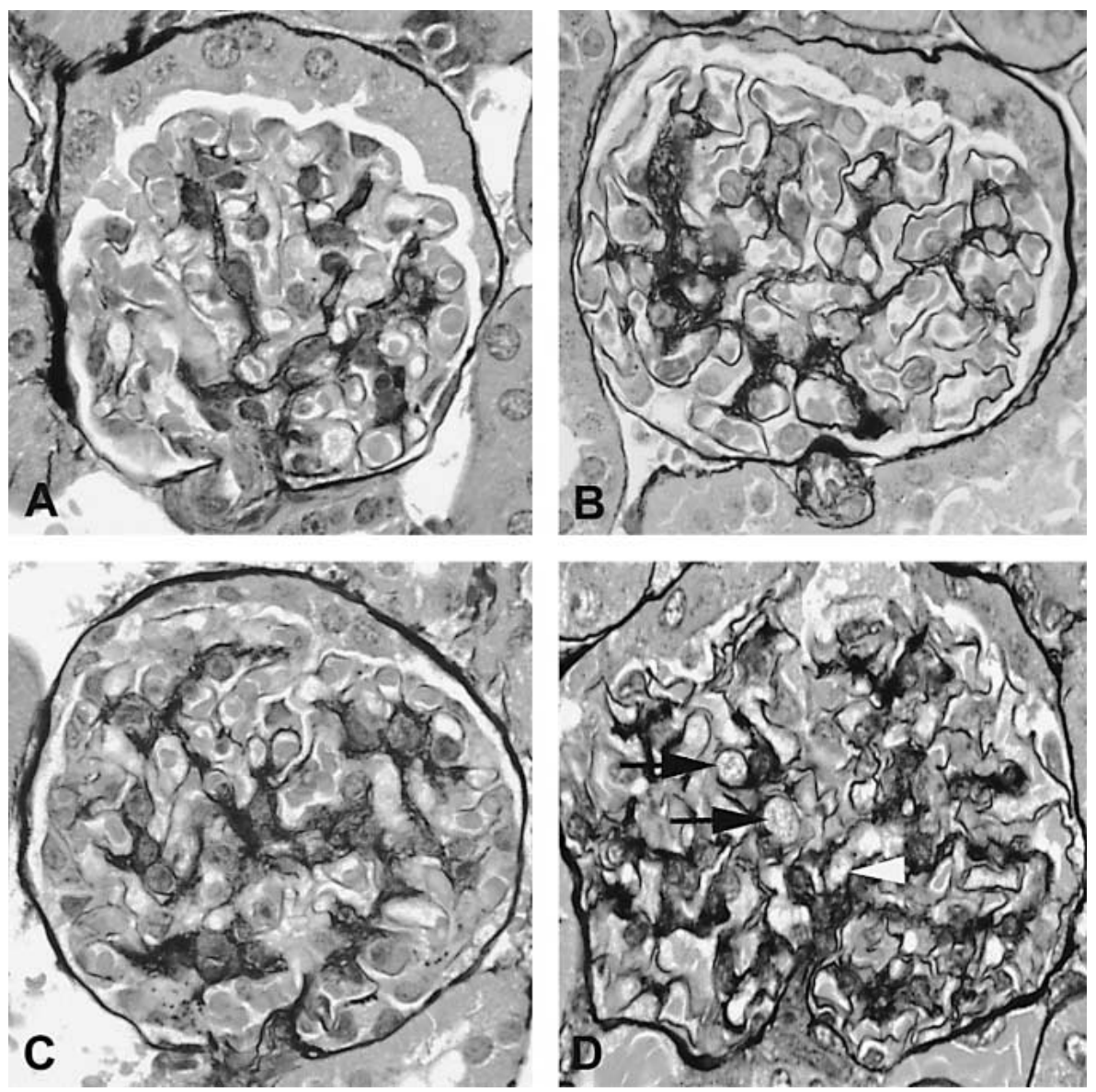

Spencer/Mühlfeld/Segerer/Hudkins/Kirk/ LeBoeuf/Alpers 
Table 2. Glomerular features

\begin{tabular}{|c|c|c|c|}
\hline & $\begin{array}{l}\text { Macrophages/ } \\
\text { gcs }\end{array}$ & $\begin{array}{l}\text { Proliferating } \\
\text { cells/gcs } \\
\text { (PCNA) }\end{array}$ & $\begin{array}{l}\alpha \text {-Smooth } \\
\text { muscle actin } \\
\text { expression/gcs }\end{array}$ \\
\hline $\begin{array}{l}1 \\
\text { BALB } \\
\text { Chow }\end{array}$ & $0.3 \pm 0.3$ & $1.6 \pm 0.3$ & $0.1 \pm 0.0$ \\
\hline $\begin{array}{l}2 \\
\text { BALB } \\
\text { Western diet }\end{array}$ & $0.4 \pm 0.1$ & $1.5 \pm 0.3$ & $0.1 \pm 0.0$ \\
\hline $\begin{array}{l}3 \\
\text { BALB } \\
\text { Chow } \\
\text { STZ }\end{array}$ & $0.4 \pm 0.1$ & $1.2 \pm 0.4$ & $0.1 \pm 0.0$ \\
\hline $\begin{array}{l}4 \\
\text { BALB } \\
\text { Western diet } \\
\text { STZ }\end{array}$ & $0.5 \pm 0.1$ & $1.7 \pm 0.3$ & $0.2 \pm 0.0$ \\
\hline $\begin{array}{l}5 \\
\text { BALB.LDLR-/- } \\
\text { Chow }\end{array}$ & $0.2 \pm 0.1$ & $1.3 \pm 0.2$ & $0.2 \pm 0.2$ \\
\hline $\begin{array}{l}6 \\
\text { BALB.LDLR-/- } \\
\text { Western diet }\end{array}$ & $0.4 \pm 0.1$ & $2.1 \pm 0.2$ & $0.1 \pm 0.0$ \\
\hline $\begin{array}{l}7 \\
\text { BALB.LDLR-/- } \\
\text { Chow } \\
\text { STZ }\end{array}$ & $0.4 \pm 0.1$ & $1.8 \pm 0.2$ & $0.1 \pm 0.0$ \\
\hline $\begin{array}{l}8 \\
\text { BALB.LDLR-/- } \\
\text { Western diet } \\
\text { STZ }\end{array}$ & $\begin{array}{l}1.9 \pm 0.2 \\
* * *, \# \#\end{array}$ & $1.7 \pm 0.3$ & $0.1 \pm 0.0$ \\
\hline
\end{tabular}

Values are expressed as mean \pm standard error of the mean. Significant differences compared to BALB controls on chow (1): *** $\mathrm{p}<$ 0.001 ; significant differences compared to diabetic controls (3): $\#$ \# $<0.001$.

cal segmental sclerosis was noted and there was no increase in glomerular expression of $\alpha$-smooth muscle actin in any of the experimental groups (table 2).

Glomeruli from control mice, BALB.LDLR-/- mice fed the Western diet or hyperglycemic STZ-treated mice were only occasionally infiltrated with macrophages (table 2). In contrast, hyperglycemic and hyperlipidemic BALB.LDLR-/- mice had significantly increased numbers of glomerular macrophages $(1.9 \pm 0.2 / \mathrm{gcs})$ compared to BALB mice $(0.3 \pm 0.3 / \mathrm{gcs}, \mathrm{p}<0.001)$, as well as BALB mice that were treated with STZ $(0.4 \pm 0.1 / \mathrm{gcs}, \mathrm{p}<0.001)$ or hyperlipidemic BALB.LDLR-/- mice $(0.4 \pm 0.1 / \mathrm{gcs}$, $\mathrm{p}<0.001$ ) (table 2; fig. 4). Glomerular proliferation was at a low level in all experimental groups with only occasional positive staining for the proliferation marker PCNA and remained unaltered by the induction of diabetes mellitus or hyperlipidemia either alone or in combination. The extent of glomerular cell death, as assessed by TUNEL staining, revealed no differences between experimental groups.

\section{Hyperlipidemic BALB.LDLR-/- Mice with \\ STZ-Induced Diabetes Mellitus Show Prominent \\ Tubulointerstitial Damage}

While BALB.LDLR-/- mice fed rodent chow did not show significant tubular or interstitial pathology, mice fed the Western diet, leading to significant hyperlipidemia, demonstrated some lipid deposition in tubular epithelial cells. Occasionally, interstitial foam cells were seen. Diabetic BALB mice had no remarkable tubulointerstitial changes. In contrast, hyperglycemic BALB.LDLR-/- animals fed the Western diet showed a high degree of tubular degeneration, with large amounts of lipids deposited in the tubular epithelial cells. Foam cells were frequently present in the interstitium. Interstitial macrophage influx, assessed as mac- 2 positive cells per $20 \times$ high power field, was also increased in these mice compared to normoglycemic $(7.5 \pm 0.9 /$ field vs. $2.6 \pm 0.6 /$ field, $\mathrm{p}<0.01)$ and hyperglycemic BALB control mice ( $7.5 \pm 0.9 /$ field vs. 2.7 \pm 1.1 /field, $\mathrm{p}<0.01$ ) (table 3).

Tubulointerstitial fibrosis, as it is seen in later stages of human diabetic nephropathy, was not present in these mice at the early timepoint studied and no significant interstitial cell expression of $\alpha$ smooth muscle actin was noted in any of the study animals.

Similarly, neither hyperlipidemia nor hyperglycemia alone significantly influenced tubulointerstitial cell proliferation. However, tubulointerstitial proliferation was significantly increased in combined diabetic and hyperlipidemic BALB.LDLR-/- mice compared to mice that were only hyperglycemic $(14.2 \pm 2.0$ cells $/ 20 \times$ high power field vs. $7.6 \pm 1.4$ cells $/ 20 \times$ high power field, $\mathrm{p}<0.05$ ) (table 3). Tubulointerstitial apoptotic cell death was also increased in these animals $(64.3 \pm 18.9$ cells $/ 20 \times$ high power field vs. $12.5 \pm 3.8$ cells $/ 20 \times$ high power field, $\mathrm{p}<0.01$ ), while neither hyperlipidemia nor hyperglycemia alone was able to induce significant amounts of apoptosis. Histological examination identified most proliferating and TUNEL positive cells as tubular epithelial cells (fig. 5), indicating increased tubular cell turnover (table 3). 

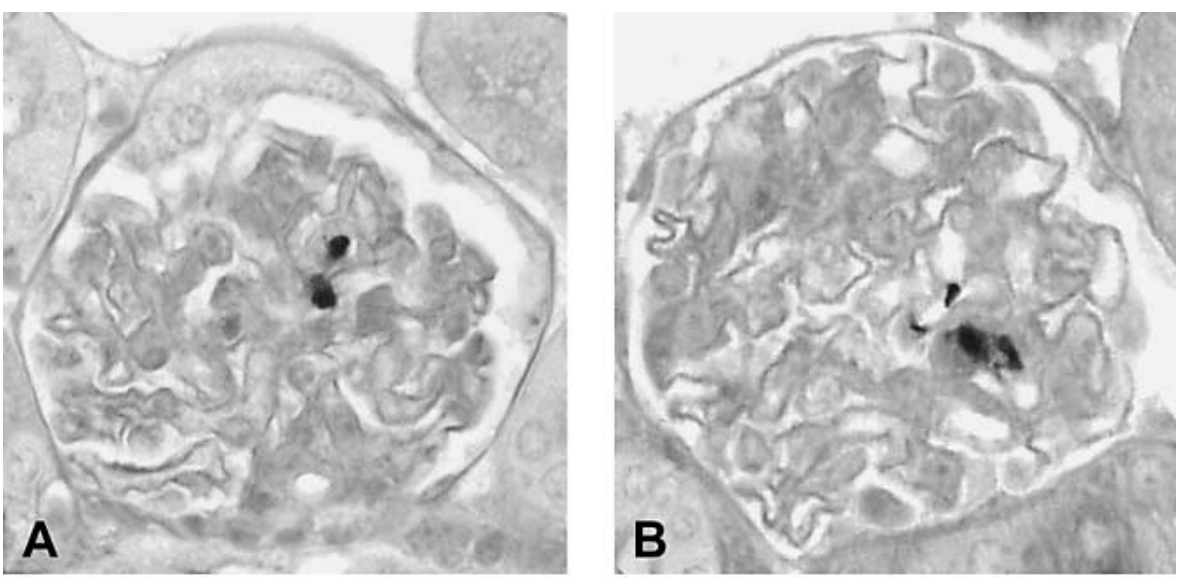

Fig. 4. A-D Glomeruli of experimental animals stained with PAS/methyl green. Immunohistochemistry for macrophages (antimac-2 stain) has been performed. A Glomerulus of a chow-fed BALB mouse. B Example of a typical glomerulus of a mouse made diabetic with STZ. C Slight increase in glomerular macrophage count in hyperlipidemic BALB.LDLR-/- mice fed the Western diet. D Strongly increased glomerular macrophage influx in BALB.LDLR-/- mice after exposure to a Western diet and STZ-induced hyperglycemia. Picture E shows strong increase of interstitial macrophages/foam cells in hyperglycemic BALB.LDLR-/- mice fed the Western diet. Mac-2 immunohistochemistry with PAS/methyl green counterstain.
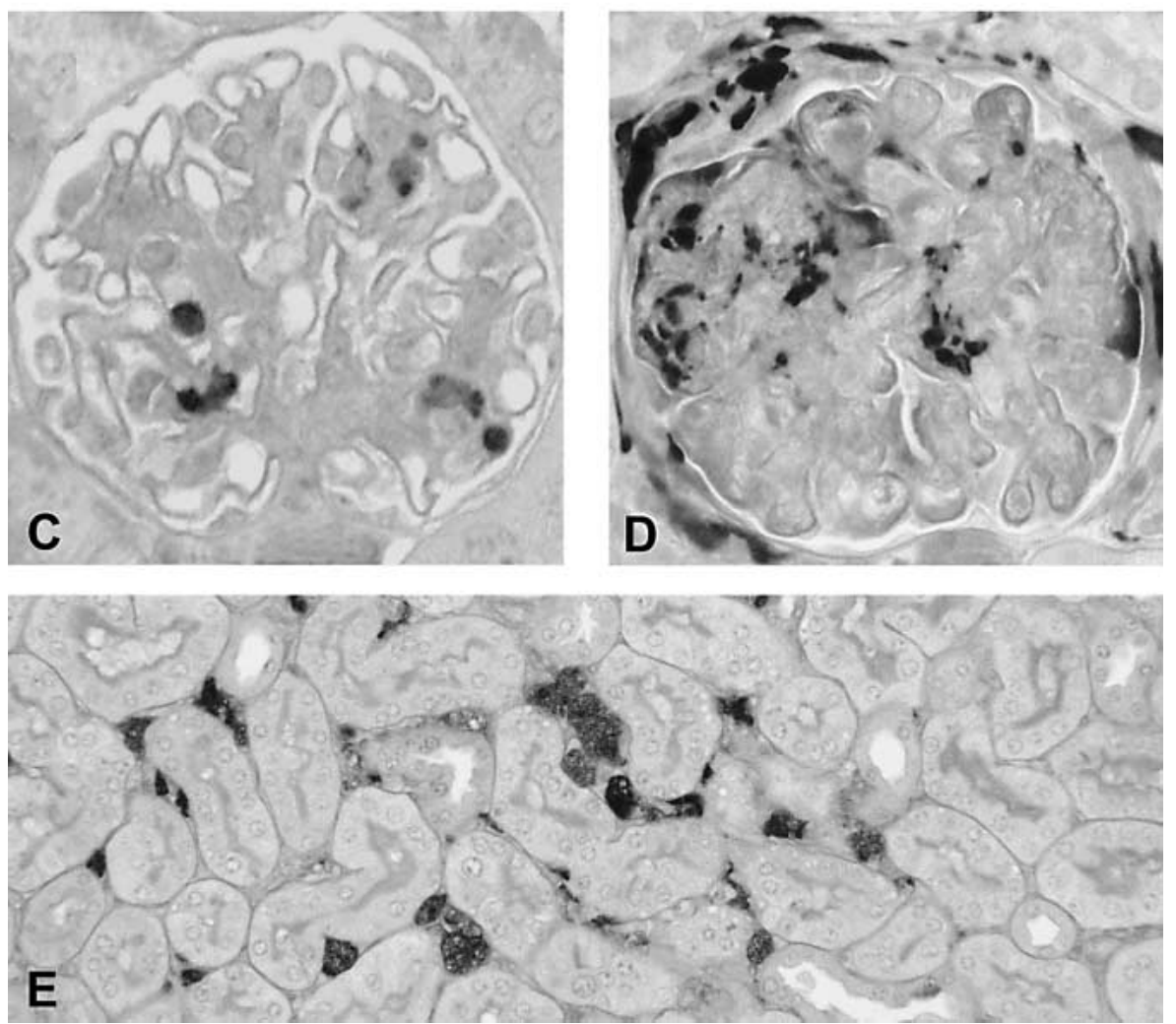

Combined Hyperlipidemia and Hyperglycemia Led to a Reduction in Excretory Kidney Function in

BALB.LDLR-/- Mice

Feeding the Western diet or STZ treatment alone resulted in only modest increases in plasma blood urea nitrogen (BUN), which did not reach the level of statistical significance when compared to controls. Excretory renal function in hyperlipidemic BALB.LDLR-/- mice was also not affected. However, both conditions together (Western diet and STZ treatment in BALB.LDLR-/- mice) led to a significant increase in plasma BUN values from $22 \pm 2$ to $69 \pm 4 \mathrm{mg} / \mathrm{dl}(\mathrm{p}<0.01$; table 1$)$ corresponding to the glomerular and tubulointerstitial pathology.

\section{Electron Microscopy}

Electron microscopy was performed on selected hyperglycemic BALB.LDLR-/- mice fed the Western diet. Ultrastructural pathology in these animals was modest with focal effacement of the podocyte foot processes and focal loss of fenestration of glomerular endothelial cells 

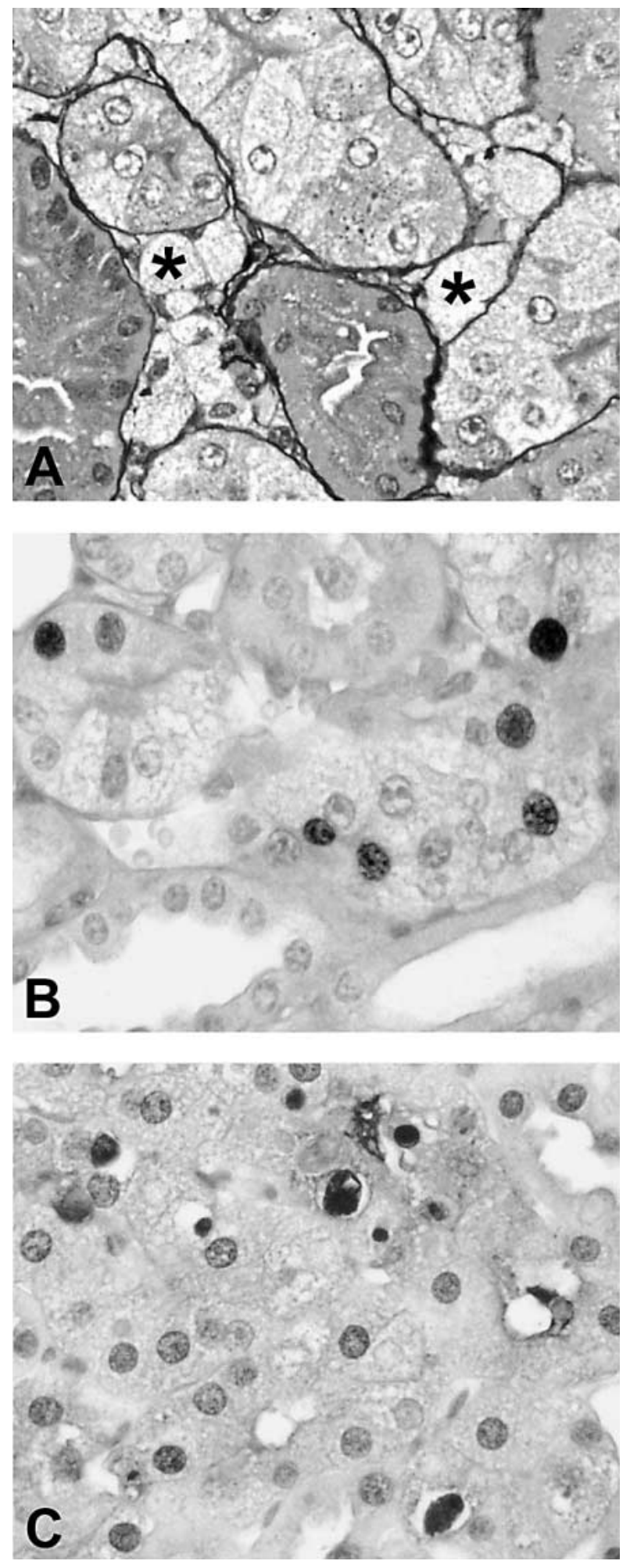

Table 3. Tubulointerstitial injury markers

\begin{tabular}{|c|c|c|c|}
\hline & $\begin{array}{l}\text { Macrophages } \\
\text { (Mac-2) }\end{array}$ & $\begin{array}{l}\text { Proliferating } \\
\text { cells (PCNA) }\end{array}$ & $\begin{array}{l}\text { TUNEL- } \\
\text { positive cells }\end{array}$ \\
\hline $\begin{array}{l}1 \\
\text { BALB } \\
\text { Chow }\end{array}$ & $2.6 \pm 0.6$ & $4.4 \pm 0.9$ & $4.5 \pm 1.1$ \\
\hline $\begin{array}{l}2 \\
\text { BALB } \\
\text { Western diet }\end{array}$ & $2.6 \pm 0.7$ & $5.7 \pm 1.2$ & $7.1 \pm 1.2$ \\
\hline $\begin{array}{l}3 \\
\text { BALB } \\
\text { Chow } \\
\text { STZ }\end{array}$ & $2.7 \pm 1.1$ & $7.6 \pm 1.4$ & $12.5 \pm 3.8$ \\
\hline $\begin{array}{l}4 \\
\text { BALB } \\
\text { Western diet } \\
\text { STZ }\end{array}$ & $2.8 \pm 0.7$ & $5.7 \pm 1.0$ & $18.0 \pm 6.2$ \\
\hline $\begin{array}{l}5 \\
\text { BALB.LDLR-/- } \\
\text { Chow }\end{array}$ & $1.2 \pm 0.2$ & $3.3 \pm 0.6$ & $6.5 \pm 1.2$ \\
\hline $\begin{array}{l}6 \\
\text { BALB.LDLR-/- } \\
\text { Western diet }\end{array}$ & $1.9 \pm 0.5$ & $4.4 \pm 0.4$ & $10.4 \pm 1.9$ \\
\hline $\begin{array}{l}7 \\
\text { BALB.LDLR-/- } \\
\text { Chow } \\
\text { STZ }\end{array}$ & $4.1 \pm 0.9$ & $5.4 \pm 0.7$ & $21.6 \pm 5.2$ \\
\hline $\begin{array}{l}8 \\
\text { BALB.LDLR-/- } \\
\text { Western diet } \\
\text { STZ }\end{array}$ & $\begin{array}{l}7.5 \pm 0.9 \\
* *, \# \#\end{array}$ & $\begin{array}{l}14.2 \pm 2.0 \\
* * *, \#\end{array}$ & $\begin{array}{c}64.3 \pm 18.9 \\
* *, \# \#\end{array}$ \\
\hline
\end{tabular}

Values are expressed as mean \pm standard error of the mean. Significant differences compared to BALB controls on chow (1): $* * \mathrm{p}<$ $0.01,{ }^{* * *} \mathrm{p}<0.001$; significant differences compared to diabetic controls on chow (3): ${ }^{\#} \mathrm{p}<0.05$, ${ }^{\#} \mathrm{p}<0.01$.

Fig. 5. Tubular changes in hyperglycemic BALB.LDLR-/- mice fed the Western diet. A 'Foamy' degeneration of tubular epithelial cells, asterisks indicate interstitial foam cells. Periodic acid methenamine silver stain. B Immunohistochemistry for PCNA (cellular proliferation marker), dark nuclei represent positive cells, note also tubular degeneration in affected area. C TUNEL staining for apoptotic cell death, dark nuclear staining indicates apoptosis. 
Fig. 6. Electron transmission microscopy of the kidneys of selected hyperglycemic BALB.LDLR-/- mice fed the Western diet. A Glomerular capillary loop, arrow points to endothelial cell changes with enlarged subendothelial space. B Glomerular capillary loop, arrow points to mesangial lipid drop, arrowheads indicate epithelial changes with effacement of foot processes.
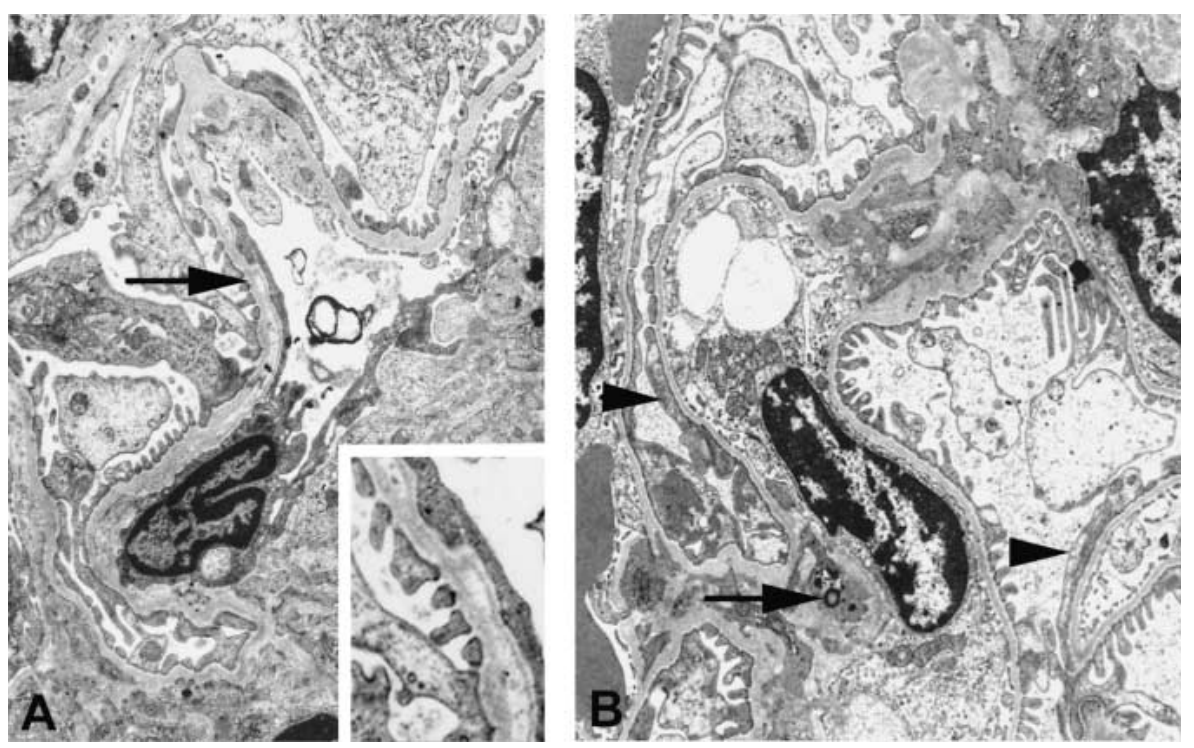

(fig. 6). Small droplets of lipids could occasionally be seen in the mesangium. Similarly, tubular epithelial cells displayed intracellular lipids but little architectural alteration. The tubular brush border and the basolateral cellular interdigitations remained largely intact.

\section{Discussion}

We studied a newly created murine strain, the BALB. LDLR-/- mouse, and subjected this strain to additional stresses of exacerbated hyperlipidemia and hyperglycemia in an attempt to develop a murine model of human diabetic nephropathy that reproduced the key features of this nephropathy better than other currently available murine models. Under the combined stress of hyperlipidemia and hyperglycemia, these mice developed glomerular changes seen in early human diabetic nephropathy including increases in cellularity and in mesangial extracellular matrix. Additional renal injury, seemingly the result of hyperlipidemia, but requiring hyperglycemia for its full development, was present in the form of glomerular infiltration of fat droplets and foam cells, tubulointerstitial injury characterized by widespread tubular degeneration accompanied by increased turnover of tubular epithelial cells and a significant increase in interstitial macrophages/foam cells. These animals also showed significantly elevated levels of blood urea nitrogen, indicating that the pathological changes lead to some degree of renal functional impairment. These findings lead us to consider that alterations of lipid metabolism may be important for successful development of murine models for diabetic nephropathy.

Hyperlipidemia is well established as a risk factor for cardiovascular disease and has been suggested to contribute to renal injury. Although human studies have not been able to demonstrate increased incidence of renal disease in patients with dyslipidemia [30], there is evidence that it may be a risk factor for the progression of preexisting renal disease [31, 32]. The pathophysiologic mechanisms by which hyperlipidemia exerts its harmful effects on the kidney are still poorly understood.

One possibility is direct injury by lipids and lipoproteins. The kidney, both glomeruli and the tubulointerstitium, may be a preferred location for lipid deposition in hyperlipidemic states because of the presence of fenestrated endothelium in glomerular and peritubular capillaries, increasing the accessibility of these locations for circulating lipids. In vitro studies have demonstrated that circulating plasma lipoproteins can be trapped in the glomeruli where they bind to extracellular matrix [33]. There they can either be taken up by resident mesangial cells [34], or endocytosed by monocytes/macrophages, which then become foam cells. Studies have also established that mesangial cells are able to oxidize lipoproteins and endocytose them via a specific scavenger receptor $[33,35]$. In vitro exposure of mesangial cells to lipoproteins leads to increased cellular proliferation rates [34, 36, 37]. Lipoproteins can also induce the release of cytokines, like TGF- $\beta$ and PDGF $[36,38]$ and increase the expression of che- 
moattractants like m-CSF and MCP-1 by mesangium cells [39-41]. LDL has also been found to promote in vitro mRNA expression of collagen IV and fibronectin, major components of the extracellular matrix [41, 42]. Our studies indicate a synergistic effect of hyperlipidemia to glomerular injury of hyperglycemia, but do not define the specific pathways by which this occurs.

A second possibility by which hyperlipidemia promotes renal injury involves a primary role for macrophages as mediators of non-immune glomerular injury. The involvement of macrophages in the development of lipid-induced nephropathy has been emphasized in renal injury either induced by diets rich in cholesterol or by genetic predisposition $[10,11,43]$. Dietary hypercholesterolemia has been shown to induce glomerular macrophage influx in rats, while hypertriglyceridemia had no corresponding influence on the amount of macrophages present in the glomeruli [11]. The obese Zucker rat, a strain where the mutation in the $f a$ gene leads to hyperphagia associated with obesity, hyperlipidemia, and later, impaired glucose tolerance through increased peripheral insulin resistance, demonstrates an early increase in glomerular monocyte/macrophage influx at the age of 6 weeks, well before any other renal changes can be detected and at a time point when blood glucose levels are still unaltered [44]. In accordance with this data, our study demonstrates increased influx of macrophages and foam cells into glomeruli of hyperlipidemic, hyperglycemic mice compared to glomeruli of mice that were exposed to only one of these factors. The relevance of these macrophages is suggested by studies that indicate that macrophages in hyperlipidemic nephropathy can lead to an increase in glomerular TGF- $\beta$ and fibronectin expression $[43,45]$, and that the involvement of macrophages in early renal injury of STZ-induced diabetes mellitus (8 days after induction of hyperglycemia) leads to an increase in glomerular collagen IV mRNA that could be reduced, but not completely reversed, by insulin treatment or irradiation-induced depletion of macrophages [46]. Thus, the local accumulation of macrophages, although not characteristic of morphologically advanced diabetic nephropathy in humans, may act synergistically with hyperglycemia by secreting growth factors and cytokines to induce fibrotic processes that may be important early in the development of the disease. This scenario is supported by the results of our study that show increased extracellular matrix in the glomeruli of hyperlipidemic and hyperglycemic mice.

Although the most distinctive features of diabetic nephropathy occur in the glomeruli, tubulointerstitial changes represent a major aspect of chronic diabetic renal disease. It is now well accepted that chronic tubulointerstitial injury including interstitial infiltration of mononuclear cells and interstitial fibrosis is the major determinant for the progression of renal disease [47]. Studies in human biopsies have shown that the decline in renal function correlates most closely with changes in the tubules and the interstitium, rather than in the glomeruli $[48,49]$. STZ-induced diabetes mellitus, the most widespread animal model for type I diabetes, does not lead to significant changes in the tubulointerstitium and does not progress to renal insufficiency, rendering this model less than satisfactory as an experimental model for human diabetic nephropathy. In this study, we attempted to model human diabetic pathology more closely by adding a second risk factor for the development of kidney disease to an established model of experimental diabetes mellitus. We were able to demonstrate significant tubular injury in hyperlipidemic BALB.LDLR-/- knockout mice made diabetic with STZ and fed the high-fat Western diet. Pathologic changes included prominent lipid deposition in tubular epithelial cells, increased influx of monocytes/ macrophages into the tubulointerstitium and increased proliferation of tubular epithelial cells. The high proliferation rates were accompanied by high levels of apoptotic cells in the tubules of affected animals. Limited amounts of tubular cell apoptosis have been described in STZinduced diabetic nephropathy later in the disease at 24 weeks [50], but mice in our study demonstrated only very limited apoptotic cell death in the tubulointerstitium after 12 weeks of hyperglycemia. It would appear that the proapoptotic effect of hyperglycemia on renal tubules observed by us and others may be aggravated by the additional damaging effect of increased tubular lipid accumulation as shown in our hyperlipidemic, hyperglycemic mice. The consequence of this tubular injury is not clear, as these mice did not develop significant interstitial fibrosis after 10 weeks of experiencing both hyperglycemia and hyperlipidemia. Long time frames for the development of the fibrosing injury may be required, as it is for human diabetic nephropathy.

In summary, our results indicate that hyperlipidemia and hyperglycemia act synergistically in inducing renal injury. This is consistent with the situation in humans, in which patients with primary hyperlipidemia have no clearly defined increased incidence of renal disease, but in whom lipids may act synergistically in the initiation and progression of diabetic nephropathy [51]. BALB. LDLR-/- mice represent a new model to study the interaction between STZ-induced diabetes mellitus and hyper- 
lipidemia [52]. These mice demonstrate the characteristic glomerular changes of murine diabetic nephropathy but have the additive feature of tubular pathology. We believe this model of diabetic nephropathy in a hyperlipidemic mouse strain may be a useful tool to address the function- al impact of both factors on the kidney, but additional model development is required to produce the characteristic microvascular and arteriolar injury of human diabetic nephropathy in mice.

\section{References}

1 USRDS 2001 Annual Data Report from Renal Data System: Bethesda, National Institute of Health, National Institute of Diabetes and Digestive and Kidney Disease, 2001.

2 Colhoun HM, Lee ET, Bennett PH, et al: Risk factors for renal failure: The WHO Multinational Study of Vascular Disease in Diabetes. Diabetologia 2001;44(suppl 2):S46-53

3 Krolewski AS, Laffel LM, Krolewski M, et al: Glycosylated hemoglobin and the risk of microalbuminuria in patients with insulin-dependent diabetes mellitus. N Engl J Med 1995;332: 1251-1255.

4 Joint Working Party on Diabetic Renal Failure of the British Diabetic Association, the Renal Association and the Research Unit of the Royal College of Physicians: Renal Failure in Diabetics in the UK: Deficient provision of care in 1985. Diabetic Med 1988;5:79-84.

5 United States Renal Data Systems: Annual report: Causes of ESRD. Am J Kidney Dis 1990; 15:22-27.

6 Torffvit O, Agardh CD: The impact of metabolic and blood pressure control on incidence and progression of nephropathy: A 10-year study of 385 type 2 diabetic patients. J Diab Compl 2001;15:307-313.

7 Harvey JN, Rizvi K, Craney L, et al: Population-based survey and analysis of trends in the prevalence of diabetic nephropathy in type 1 diabetes. Diab Med 2001;18:998-1002.

8 Turner RC, Millns H, Neil HA, et al: Risk factors for coronary artery disease in non-insulin dependent diabetes mellitus: United Kingdom Prospective Diabetes Study (UKPDS: 23). BMJ 1998;316:823-828.

9 Guijarro C, Kasiske BL, Kim Y, et al: Early glomerular changes in rats with dietary-induced hypercholesterolemia. Am J Kidney Dis 1995; 26:152-161.

10 Hattori M, Nikolic-Paterson DJ, Miyazaki K, et al: Mechanisms of glomerular macrophage infiltration in lipid-induced renal injury. Kidney Int Suppl 1999;71:S47-50.

11 Joles JA, Kunter U, Janssen U, et al: Early mechanisms of renal injury in hypercholesterolemic or hypertriglyceridemic rats. J Am Soc Nephrol 2000;11:669-683.

12 Kasiske BL, O’Donnell MP, Schmitz PG, et al Renal injury of diet-induced hypercholesterolemia in rats. Kidney Int 1990;37:880-891.

13 Kamanna VS, Kirschenbaum MA: Association between very-low-density lipoprotein and glomerular injury in obese Zucker rats. Am J Nephrol 1993;13:53-58.
14 Wen M, Segerer S, Dantas M et al: Renal injury in apolipoprotein e-deficient mice. Lab Invest 2002;82:999-1006

15 Mulec H, Johnson SA, Bjorck S: Relation between serum cholesterol and diabetic nephropathy. Lancet 1990;335:1537-1538.

16 Krolewski AS, Warram JH, Christlieb AR: Hypercholesterolemia - a determinant of renal function loss and deaths in IDDM patients with nephropathy. Kidney Int Suppl 1994;45: S125-131.

17 Silveiro SP, Friedman R, Gross JL: Glomerular hyperfiltration in NIDDM patients without overt proteinuria. Diab Care 1993;16:115119.

18 Ravid M, Brosh D, Ravid-Safran D, et al: Main risk factors for nephropathy in type 2 diabetes mellitus are plasma cholesterol levels, mean blood pressure, and hyperglycemia. Arch Intern Med 1998;158:998-1004.

19 Jerums G, Allen TJ, Tsalamandris C, et al: Relationship of progressively increasing albuminuria to apoprotein(a) and blood pressure in type 2 (non-insulin-dependent) and type 1 (insulin-dependent) diabetic patients. Diabetologia 1993;36:1037-1044.

20 Yokota C, Kimura G, Inenaga T, et al: Risk factors for progression of diabetic nephropathy. Am J Nephrol 1995; 15:488-492.

21 Shoji T, Nishizawa Y, Toyokawa A, et al: Decreased albuminuria by pravastatin in hyperlipidemic diabetics. Nephron 1991;59:664665.

22 Sasaki T, Kurata H, Nomura K, et al: Amelioration of proteinuria with pravastatin in hypercholesterolemic patients with diabetes mellitus. Jpn J Med 1990;29:156-163.

23 Tonolo G, Ciccarese M, Brizzi P, et al: Reduction of albumin excretion rate in normotensive microalbuminuric type 2 diabetic patients during long-term simvastatin treatment. Diab Care 1997;20:1891-1895.

24 Segerer S, Hudkins KL, Taneda S, et al: Oral interferon-alpha treatment of mice with cryoglobulinemic glomerulonephritis. Am J Kidney Dis 2002;39:876-888.

25 Hugo C, Shankland SJ, Bowen-Pope DF, et al: Extraglomerular origin of the mesangial cell after injury: A new role of the juxtaglomerular apparatus. J Clin Invest 1997;100:786-794.

26 Hiromura K, Haseley LA, Zhang P, et al: Podocyte expression of the CDK-inhibitor p57 during development and disease. Kidney Int 2001; 60:2235-2246.
27 Segerer S, Eitner F, Cui Y, et al: Cellular injury associated with renal thrombotic microangiopathy in human immunodeficiency virus-infected macaques. J Am Soc Nephrol 2002;13: 370-378.

28 Alpers CE, Hudkins KL, Pritzl P, et al: Mechanisms of clearance of immune complexes from peritubular capillaries in the rat. Am J Pathol 1991;139:855-867.

29 Alpers CE, Hudkins KL, Gown AM, et al: Enhanced expression of 'muscle-specific' actin in glomerulonephritis. Kidney Int 1992;41: 1134-1142.

30 Smellie WS, Warwick GL: Primary hyperlipidaemia is not associated with increased urinary albumin excretion. Nephrol Dial Transplant 1991;6:398-401.

31 Keane WF: The role of lipids in renal disease: Future challenges. Kidney Int Suppl 2000;75: S27-31.

32 Attman PO, Alaupovic P, Samuelsson O: Lipoprotein abnormalities as a risk factor for progressive nondiabetic renal disease. Kidney Int Suppl 1999;71:S14-17.

33 Schlondorff D: Cellular mechanisms of lipid injury in the glomerulus. Am J Kidney Dis 1993;22:72-82.

34 Wasserman J, Santiago A, Rifici V, et al: Interactions of low density lipoprotein with rat mesangial cells. Kidney Int 1989;35:1168-1174.

35 Wheeler DC, Chana RS, Topley N, et al: Oxidation of low density lipoprotein by mesangial cells may promote glomerular injury. Kidney Int 1994;45:1628-1636.

36 Nishida Y, Yorioka N, Oda H, et al: Effect of lipoproteins on cultured human mesangial cells. Am J Kidney Dis 1997;29:919-930.

37 Coritsidis G, Rifici V, Gupta S, et al: Preferential binding of oxidized LDL to rat glomeruli in vivo and cultured mesangial cells in vitro. Kidney Int 1991;39:858-866.

38 Grone EF, Abboud HE, Hohne M, et al: Actions of lipoproteins in cultured human mesangial cells: Modulation by mitogenic vasoconstrictors. Am J Physiol 1992;263:F686-696.

39 Kamanna VS, Pai R, Roh DD, et al: Oxidative modification of low-density lipoprotein enhances the murine mesangial cell cytokines associated with monocyte migration, differentiation, and proliferation. Lab Invest 1996;74: 1067-1079.

40 Kim SY, Guijarro C, O’Donnell MP, et al: Human mesangial cell production of monocyte chemoattractant protein-1: Modulation by lovastatin. Kidney Int 1995;48:363-371. 
41 Rovin BH, Tan LC: LDL stimulates mesangial fibronectin production and chemoattractant expression. Kidney Int 1993;43:218-225.

42 Kim SB, Kang SA, Cho YJ, et al: Effects of low density lipoprotein on type IV collagen production by cultured rat mesangial cells. Nephron 1994;67:327-333.

43 Ding G, Pesek-Diamond I, Diamond JR: Cholesterol, macrophages, and gene expression of TGF-beta 1 and fibronectin during nephrosis. Am J Physiol 1993;264:F577-584.

44 Coimbra TM, Janssen U, Grone HJ, et al: Early events leading to renal injury in obese Zucker (fatty) rats with type II diabetes. Kidney Int 2000;57:167-182.
45 Ding G, van Goor H, Frye J, et al: Transforming growth factor-beta expression in macrophages during hypercholesterolemic states. Am J Physiol 1994;267:F937-943.

46 Sassy-Prigent C, Heudes D, Mandet C, et al: Early glomerular macrophage recruitment in streptozotocin-induced diabetic rats. Diabetes 2000;49:466-475.

47 Nath KA: Tubulointerstitial changes as a major determinant in the progression of renal damage. Am J Kidney Dis 1992;20:1-17.

48 Schainuck LI, Striker GE, Cutler RE, et al: Structural-functional correlations in renal disease. II. The correlations. Hum Pathol 1970;1: 631-641.
49 Striker GE, Schainuck LI, Cutler RE, et al: Structural-functional correlations in renal disease. I. A method for assaying and classifying histopathologic changes in renal disease. Hum Pathol 1970;1:615-630.

50 Makino H, Sugiyama H, Kashihara N: Apoptosis and extracellular matrix-cell interactions in kidney disease. Kidney Int Suppl 2000;77:S6775.

51 Gin H, Rigalleau V, Aparicio M: Lipids, protein intake, and diabetic nephropathy. Diabetes Metab 2000;26(suppl 4):45-53.

52 Bonnet F, Cooper ME: Potential influence of lipids in diabetic nephropathy: Insights from experimental data and clinical studies. Diabetes Metab 2000;26:254-264. 